https://nv.nltu.edu.ua

https://doi.org/10.36930/40310117

$@ \bowtie$ Correspondence author

Article received 25.01.2021 p.

Article accepted 04.02.2021 p.

M. S. Malovanyy

UDC 606:628

myroslav.mal@gmail.com

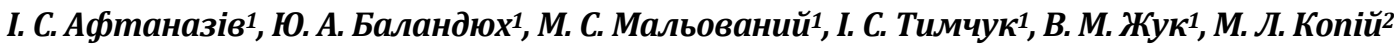

${ }^{I}$ Начіональний університет "Львівська політехніка", м. Львів, Украӥна,

${ }^{2}$ Наиіональний лісотехнічний університет України, м. Львів, Україна,

\title{
ВПЛИВ ВІБРОКАВІТАЦІЙНОГО ОБРОБЛЕННЯ СУСПЕНЗІЇ ЦІАНОБАКТЕРІЙ НА ІНТЕНСИВНІСТЬ СИНТЕЗУ БІОГАЗУ
}

Досліджено вплив віброкавітаційного оброблення біомаси суспензії ціанобактерій на інтенсивність та ефективність синтезу біогазу внаслідок реалізації в подальшому процесу метаногенезу. Показано актуальність розроблення технології утилізації надлишкової біомаси ціанобактерій, яка утворюється внаслідок їх неконтрольованого розвитку у мілководних ділянках штучних водойм і в технологіях біологічного очищення забруднених поверхневих та стічних вод. Запропоновано використання для руйнування міжклітинних перегородок ціанобактерій та вивільнення їх біомаси, яка стає доступною біорозкладу та реалізації метаногенезу, віброкавітаційного оброблення. Наведено опис конструкції віброкавітатора, який сприяє ефективній руйнації міжклітинних перегородок біомаси ціанобактерій та може працювати у безперервному режимі. Сконструйовано та використано для попереднього оброблення ціанобактерій лабораторну установку віброкавітатора, який працює у періодичному режимі. Створено дослідну установку для дослідження динаміки метаногенезу обробленої у віброкавітаторі біомаси ціанобактерій у безперервному режимі із використанням відеореєстрації синтезу біогазу та передачі даних щодо динаміки синтезу біогазу на монітор. Отримано експериментальні залежності динаміки синтезу біогазу із біомаси ціанобактерій від періоду їх оброблення у віброкавітаційному полі. Встановлено що оптимальні параметри синтезу біогазу досягаються після попереднього оброблення біомаси ціанобактерій у віброкавітаторові впродовж 15 хв. Встановлено автокаталітичний характер процесу, що дає змогу висунути припущення про підпорядкованість його рівнянню Міхаеліса - Ментена. Отриманий після закінчення процесу метаногенезу дигестат запропоновано використовувати як ефективне біоорганічне або органомінеральне (у разі створення композиції із природними дисперсними сорбентами) добриво.

Ключові слова: евтрофікація; біомаса; біорозклад; біологічне очищення; інтенсивність; метаногенз; дигестат.

\section{Вступ}

Проблему накопичення біомаси ціанобактерій, яка потребує утилізації, потрібно розглядати із двох позицій: 1) Внаслідок масового забруднення поверхневих вод сполуками азоту та фосфору із неповністю очищеними каналізаційними стоками, змитими із сільськогосподарських полів мінеральними добривами та іншими відходами антропогенної діяльності, у поверхневих водах спостерігається неконтрольований розвиток ціанобактерій [4], що спричиняє евтрофікацію водойм. Процес посилюється розвитком мілководних ділянок, які добре прогріваються сонцем, що виникли у штучних водоймах, створених для забезпечення роботи каскадів електростанцій на Дніпрі, Дністрі та інших річках України. 2) Ціанобактерії разом із іншими мікроводоростями дедалі частіше залучають до технологій біологічного очищення стічних вод як одну із стадій біологічного очищення [3]. В обох випадках нарощена внаслідок використання ціанобактеріями як елементів живлення фосфорних та азотних забруднень біомаса потребує збирання, концентрування та утилізації. У разі відсутності такої утилізації після закінчення участі ціанобактерій у циклі очищення вони підлягають відмиранню та

Інформація про авторів:

Афтаназів Іван Семенович, д-р техн. наук, доцент, завідувач кафедри нарисної геометрії та інженерної графіки. Email: ivan.aftanaziv@gmail.com; https://orcid.org/0000-0003-3484-7966

Баландюх Юрій Андрійович, аспірант, кафедра екології та збалансованого природокористування. Email: iurii.balandiukh@gmail.com; https://orcid.org/0000-0003-3280-1040

Мальований Мирослав Степанович, д-р техн. наук, доцент, завідувач кафедри екології та збалансованого природокористування. Email: myroslav.mal@gmail.com; https://orcid.org/0000-0002-3868-1070

Тимчук Іван Степанович, канд. с.-г. наук, доцент, докторант, кафедра екології та збалансованого природокористування. Email: i.s.tymchuk@gmail.com; https://orcid.org/0000-0001-9344-3035

Жук Володимир Михайлович, канд. техн. наук, доцент, кафедра гідротехніки та водної інженерії. Email: zhuk_vm@ukr.net; https://orcid.org/0000-0002-2275-0799

Копій Марія Леонідівна, канд. с.-г. наук, асистент, кафедра екології. Email: marykop16@ukr.net; https://orcid.org/0000-0003-4355-5543

Цитування за ДСтУ: Афтаназів І. С., Баландюх Ю. А., Мальований М. С., Тимчук І. С., Жук В. М., Копій М. Л. Вплив віброкавітаційного оброблення суспензії ціанобактерій на інтенсивність синтезу біогазу. Науковий вісник НлтУ України. 2021, т. 31, № 1. С. 99-104.

Citation APA: Aftanaziv, I. S., Balandiuk, Yu. A., Mallovanyy, M. S., Tymchuk, I. S., Zhuk, V. M., \& Kopiy, M. L. (2021). Influence of cyanobacteria suspension vibrocavitation treatment on the biogas synthesis intensity. Scientific Bulletin of UNFU, 31(1), 99-104. https://doi.org/10.36930/40310117 
біорозкладу і спричиняють потужне біологічне забруднення довкілля. Ефективним екологічно та економічно оправданим методом утилізації біомаси ціанобактерій $є$ використання іiї як сировини для виробництва біогазу [6].

Актуальність визначається, з одного боку, необхідністю запобігання екологічній небезпеці від біорозкладу біомаси ціанобактерій, які неконтрольовано накопичуються у поверхневих водах, а також нарощуються в системах очищення стічних і поверхневих вод, де ціанобактерії використовуються в технологічних цілях, а з іншого боку - екологічною та економічною привабливістю застосуванням технології синтезу біогазу для утилізації цієї біомаси. Внаслідок такої стратегії вдається не тільки мінімізувати екологічну небезпеку від неконтрольованого біорозкладу ціанобактерій, але й отримати цінний енергоресурс, поява якого буде сприяти підсиленню енергетичної незалежності держави. Важливим $\epsilon$ забезпечення якомога повнішого біорозкладу біомаси ціанобактерій для досягнення максимальних показників біорозкладу як щодо інтенсивності процесу, так і щодо кількості виділеного біогазу. Саме досягненню цих цілей і присвячені ці дослідження.

Встановлення перспективності та оптимальних параметрів попереднього віброкавітаційного оброблення біомаси ціанобактерій для досягнення максимальної повноти та інтенсивності біорозкладу. Критерієм ефективності попереднього оброблення є експериментальні результати, які визначають об'єм та інтенсивність синтезу біогазу із біомаси ціанобактерій.

Об'єкт дослідження - процес утилізації ціанобактерій шляхом використання їх як сировини для синтезу біогазу.

Предмет дослідження - процес попереднього віброкавітаційного оброблення біомаси ціанобактерій для руйнування клітинних перегородок та збільшення кількості біомаси, доступної для біорозкладу із утворенням біогазу.

Мета роботи - встановлення оптимальних параметрів віброкавітаційного оброблення біомаси ціанобактерій, яка дала б змогу забезпечити максимальну інтенсивність процесу метаногенезу та максимальну кількість синтезованого біогазу.

Для досягнення зазначеної мети визначено такі основні завдання дослідження: створити дослідну установку для попереднього віброкавітаціного оброблення біомаси ціанобактерій перед реалізацією їі метаногенезу; обробити біомасу за різної тривалості процесу; створити установку для дослідження динаміки метаногенезу із використанням відеонагляду за розвитком процесу; дослідити динаміку та основні особливості метаногенезу із використанням як сировини біомаси ціанобактерій; встановити оптимальний час попереднього віброкавітаційного оброблення біомаси для максимальної інтенсифікації процесу та отримання максимальної кількості біогазу.

Наукова новизна отриманих результатів дослідження - вперше експериментально встановлено оптимальний режим попереднього віброкавітаційного оброблення біомаси ціанобактерій (15 хв оброблення), яка дає змогу забезпечити максимальну інтенсивність реалізованого в подальшому процесу метаногенезу та отримати максимальну кількість біогазу.

Практична значущість результатів дослідження доведена перспектива застосування попереднього віб- рокавітаційного оброблення біомаси ціанобактерій для максимального біорозкладу цієї біомаси у реалізованому в подальшому процесі метаногенезу.

Аналіз останніх досліджень та публікацій. Використання біомаси ціанобактерій як сировини для виробництва біогазу та біодизелю досліджено у працях [2, 7, 8]. Перші етапи цих технологій споріднені і містять збір із поверхні водойм ціанобактерій, відділення їх від води у накопичувальних колонах чи спеціальних ємкостях та підготовку субстрату біомаси водоростей. Для отримання біогазу субстрат завантажують у метантенки, де за температури $60^{\circ} \mathrm{C}$ за біотехнологією "метанового бродіння" із нього ферментується біогаз, який спрямовується у газозбірник. У технології виробництва біодизельного пального субстрат біомаси піддають екстрагуванню для виділення із нього ліпідів та жирних кислот. Із цієї сировини біодизель виготовляють за традиційною технологією - переетиризацією рослинних масел $[1$, 10]. У кожному із цих технологічних процесів вихід готового продукту певною мірою лімітується ступенем розкладу сировинної біомаси (ціанобактерій), або по-іншому ступенем відкритості до масообміну локалізованої у клітинній оболонці ціанобактерій біомаси. Як відомо, оболонка цих бактерій доволі стійка до зовнішніх впливів, що зумовлює у разі відсутності попереднього оброблення низьку інтенсивність перебігу процесів синтезу біогазу та екстрагування ліпідів. У кінцевому підсумку це не дає змоги повною мірою використати енергетичний потенціал біомаси.

\section{Результати дослідження та їх обговорення}

Використання засобів механічного руйнування оболонок бактерій через невеликі їх розміри виявилось малоефективним. Тому тривають пошуки більш дієвих методів інтенсифікації виділення внутрішньоклітинного вмісту ціанобактерій. Доволі ефективний метод руйнівного впливу на ціанобактерії запропоновано у роботах $[5,6,11]$. Автори дослідили застосування кавітаційних явищ для інтенсифікації руйнування мембран та оболонок ціанобактерій 3 метою повнішого і пришвидшеного виділення їх внутрішньоклітинного вмісту.

Результати досліджень впливу гідродинамічної кавітації на ефективність екстрагування ліпідів із біомаси ціанобактерій за даними наших попередніх досліджень [6] показують, що загальний вміст ліпідів у відібраній пробі ціанобактерій становив 1,27 \% від сухої маси. Із біомаси без попереднього оброблення в полі гідродинамічної кавітації вдалося екстрагувати ліпіди у кількості, що відповідає 0,32 \% сухої маси водоростей (25,2 \% від всього вмісту ліпідів). Цей результат підтверджує, що клітинні стінки необроблених водоростей $є$ тяжко проникні, і використання їх без оброблення для отримання енергоносіїв $\epsilon$ ускладненим. Із біомаси, яка пройшла попереднє оброблення в полі гідродинамічної кавітації, за описаною вище методикою вдалось екстрагувати 0,45 \% ліпідів (майже 80 \% від всього вмісту ліпідів).

Результати порівняння кількості біогазу, добутого із біомаси без попереднього оброблення та після оброблення в полі гідродинамічної кавітації [6] показали, що попередня гідродинамічна кавітація дала змогу збільшити кількість синтезованого із біомаси водоростей біогазу майже на $30 \%$.

Кавітаційне оброблення водяної суспензії ціанобактерій, завдяки утворенню при сплескуванні кавітацій- 
них мікробульбашок ударних мікрохвиль, почергової зміни зон підвищених та понижених тисків, а також інтенсивному впливу на мембрани та оболонки водоростей самоутворюваних у кавітаційному полі хімічно активних окиснювачів радикалів $\mathrm{OH}^{--}$та пероксиду водню $\mathrm{O}_{2} \mathrm{H}_{2}^{-}$, активно руйнує оболонки водоростей та вивільняє їх внутрішньоклітинний вміст. Цей спосіб захищено патентом на корисну модель України і він передбачає на етапі "екстрагування та біорозкладу" застосування гідродинамічної кавітації [6], що на 20-25 \% підвищує швидкість руйнування оболонок ціанобактерій. Однак, очевидно, через недостатню інтенсивність формованого лопатевими кавітаторами кавітаційного поля, бажаного результату забезпечити не вдалося.

За результатами наших попередніх досліджень запропоновано принципово новий різновид кавітаційної техніки, придатної для продуктивного і високоякісного оброблення рідинних середовищ, зокрема і середовищ із підвищеною, порівняно із водою, в'язкістю [9]. Це ус-

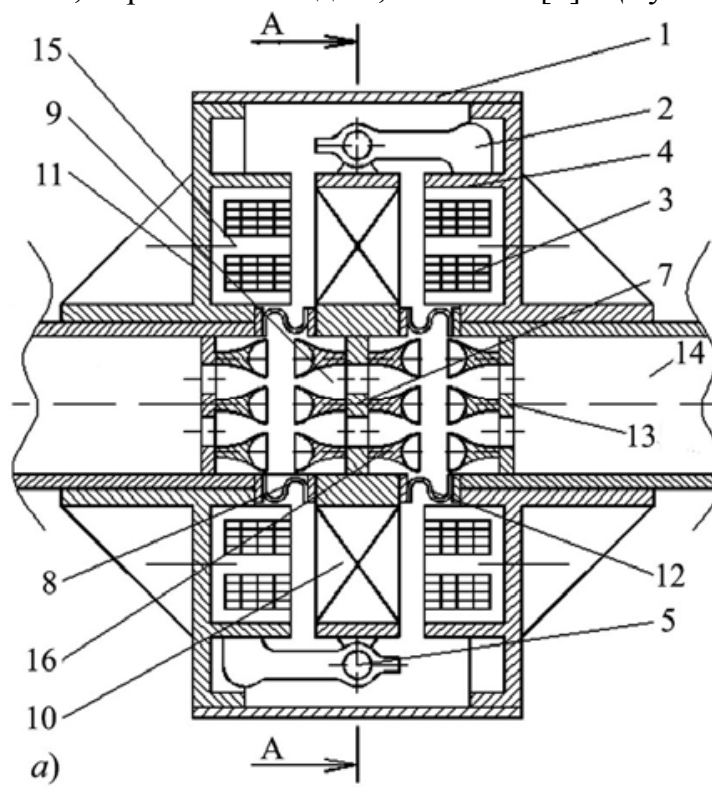

a)

таткування об'єднано спільною назвою "віброрезонансні кавітатори" і їх перевагою є спроможність до оброблення значних обсягів рідинних середовищ у неперервному їх потоці. Характерною особливістю віброрезонансних кавітаторів є збурення кавітаційного поля вібруючими деками по всьому поперечному перерізу протічної робочої камери. Дослідження на діючих експериментальних зразках віброрезонансних кавітаторів засвідчили їх придатність для якісного кавітаційного оброблення водяних суспензій ціанобактерій з метою вивільнення їх внутріклітинного вмісту. На підставі цих даних із врахуванням специфіки кавітаційного оброблення суспензій ціанобактерій було розроблено принципову схему промислового варіанта віброрезонансного кавітатора для гомогенізації біомаси ціанобактерій.

Принципову конструктивну схему віброрезонансного кавітатора для гомогенізації біомаси мікроводоростей із електромагнітним приводом зображено на рис. 1.

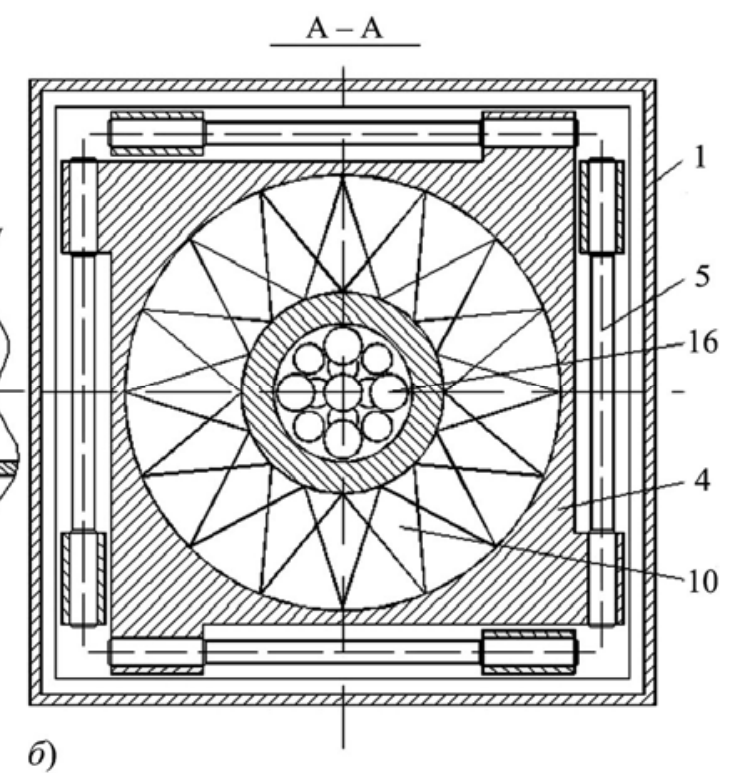

Рис. 1. Принципова схема віброрезонансного кавітатора з електромагнітним приводом для гомогенізації біомаси ціанобактерій

До складу віброкавітатора входять завантажувальна 6, робоча 9 та відвідна 14 камери. Робоча камера 9 з'єднана із завантажувальною 6 та відвідною 14 із можливістю відносних переміщень через гнучкі гофри 8 та 12. На робочій камері 9 закріплено набраний із листового заліза кільцевий якір 10, а камера та якір через кронштейни 2 та циліндричні пружні стержні 5 з'єднані із закріпленими на трубах завантажувальної 6 та відвідної 14 камер реактивних масах 11. Співвісно якореві 10 до кожної із закріплених на завантажувальній 6 та відвідній 14 камерах реактивних мас 11 прикріплено корпус 4 електромагніта. У корпусі 4 співвісно якореві 10 розташовані кільцевий статор 15 із котушкою обмотки 3. Кожен із статорів 15 із котушкою обмотки 3 та спільним якорем 10 формують два симетрично розміщених відносно якоря 10 електромагніти. Обмотки електромагнітів під'єднані до мережі змінної напруги живлення із зміщенням за фазою, що у першому півперіоді синусоїдальної змінної напруги якір притягується до одного із крайніх електромагнітів, а у другому півперіоді - до іншого електромагніта.

Співвісно розташовані статори 15 із котушками обмоток 3 та якір 10 із робочою камерою 9 утворюють кільцевий електромагнітний віброзбудник із двома електромагнітами та спільним якорем. Електромагнітний віброзбудник у поєднанні із прикріпленими до реактивної маси пружними стрижнями 5 формують двомасову резонансну коливну систему. Перша із коливних мас - наповнена оброблюваною рідиною робоча камера 9 із прикріпленим до неї якорем 10 та декою 7, друга - статори 15 із обмотками 3, реактивні маси 11 із масивними трубами завантажувальної 6 та відвідної 14 камер.

До якоря та статора жорстко прикріплені рухома 7 та нерухомі 13 деки із рівномірно розташованими на всій їхній площі отворами для протікання оброблюваної рідини. На коливній деці 7 та закріплених на корпусах статорів нерухомих деках 13 встановлені розвернуті один навпроти другого своїми торцевими поверхнями збурювачі кавітації 16, зовнішня поверхня яких виконана у формі гіперболоїда обертання, а торцева - у вигляді вписаної в гіперболоїд півсфери із радіусом, рівним подвоєному розмаху коливань робочої камери. Мінімальна віддаль між сусідніми розташованими на спільній деці збурювачами кавітації 16 рівна амплітуді коливань робочої камери 9, а віддаль між коливними та нерухомими збурювачами кавітації 16 рівна розмаху коливань деки 7. Від потрапляння сторонніх предметів до 
коливних систем електромагнітний віброзбудник захищено захисним кожухом 1.

Робота вібраційного електромагнітного кавітатора здійснюється так. Трубою завантажувальної камери 6 в робочу камеру 9 під незначним тиском або самотоком подають оброблювану рідину - водяну суспензію ціанобактерій Одночасно на обмотки 3 котушок електромагнітів із вище відзначеним зміщенням за фазою подають напругу. Електромагніти почергово притягують до себе якір 10 із наповненою оброблюваною рідиною робочою камерою 9, прогинаючи при цьому пружні циліндричні стержні 5. Прогин та пружність циліндричних стержнів 5 розраховано так, що вони забезпечують резонансні коливні режими робочої камери 9 та унеможливлюють співударяння якоря 10 та статорів 15 між собою. Почергове протягування якоря 10 до електромагнітів 15 трансформується у направлені плоскопаралельні коливні переміщення наповненої оброблюваною рідиною робочої камери 9. Ці коливання відбуваються iз певними розрахунковими амплітудами та частотою, рівною подвоєній частоті подачі напруги на котушки кільцевих електромагнітних віброзбудників. Так за частоти змінної напруги мережі живлення обмоток 3 електромагнітів 50 Гц частота коливань робочої камери 9 становитиме 100 Гц. Разом із коливною робочою камерою 9 плоскопаралельні переміщення здійснює i прикріплена до камери дека 7 із зафіксованими на ній збурювачами кавітації 16.

Обговорення результатів дослідження. На лабораторній моделі описаного вище віброкавітатора, який працював у періодичному режимі, проводили попереднє оброблення суспензії ціанобактерій 3 метою руйнування клітинних стінок та вивільнення біомаси у простір доступності для реалізації в подальшому метаногенезу.

Досліди проводили із водою, в яку вводили ціанобактерії, відібрані на Кременчуцькому водосховищі у м. Світловодськ. Перед початком експериментів водорості розбавляли до вмісту сухої речовини 17,1 г/л, що відповідає реальній концентрації водоростей у місцях скупчення.

У робочу ємкість віброкавітатора заливали 1 л модельної суспензії. Час кавітаційної одробки становив 5, 10 та 15 хв. Попередніми дослідженнями встановлено, що метаногенез у ціанобактеріях без будь-якого попереднього оброблення біомаси проходить повільно і неефективно, кількість та інтенсивність отриманого біогазу не дає підстав рекомендувати таку технологію для промислового впровадження. Оброблення біомаси більше 15 хв. також неефективна, оскільки незважаючи на збільшення підводу енергії досягти подальшого збільшення ефективності чи інтенсивності метаногенезу не вдавалось. Після віброкавітаційного оброблення проба використовувалась в подальшому для дослідження ефективності синтезу біогазу.

Метою досліджень було встановлення можливості отримання біогазу шляхом анаеробного зброджування біомаси ціанобактерій.

На першому етапі досліджень визначали вміст органічної частини водоростей способом спалювання наважки висушених водоростей у печі за $550^{\circ} \mathrm{C}$ впродовж 15 хв. За результатами досліджень органічна частина становила 94 \% від загальної маси водоростей.
Експериментальну установку для дослідження динаміки синтезу біогазу із ціанобактерій подано на рис. 2.

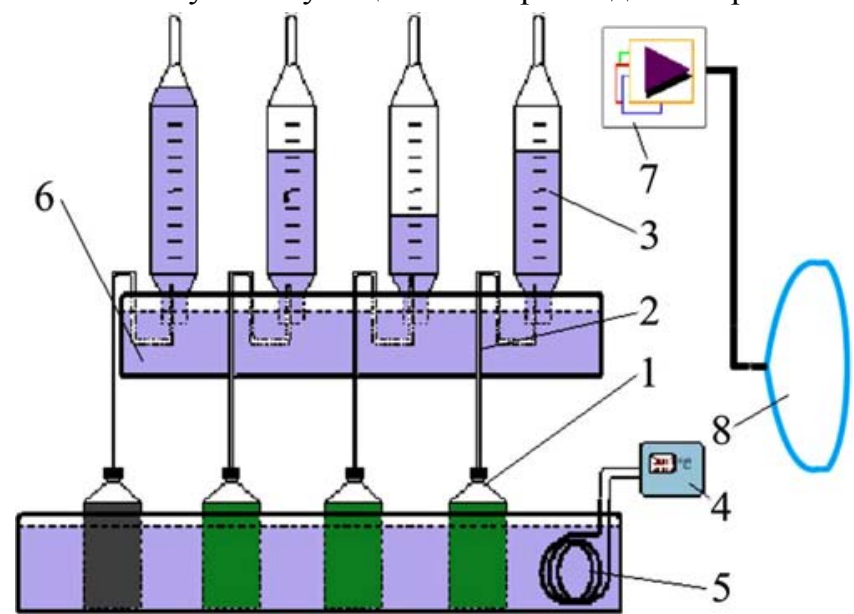

Рис. 2. Експериментальна установка дослідження процесу отримання біогазу

Для проведення експериментів з отримання біогазу для імітації складу верхнього шару водосховища, в якому міститься невелика кількість анаеробних бактерій, для інтенсифікації процесу анаеробного розкладу, проби змішували із первинним мулом очисних споруд, у якому міститься значна кількість анаеробних бактерій. До 900 мл кожної з проб добавляли по 50 мл мулу (концентрація сухої речовини 24,0 г/л; вміст органічної частини становив 69,3\%) та поміщали в окремі реактори експериментальної установки (див. рис. 2). Для того, щоб знати яка частина біогазу виділяється із мулу, а яка із водоростей, готували нульову пробу способом змішування 50 мл мулу із 900 мл води, яку поміщали у реактор 1. Отримані розчини водоростей мали $\mathrm{pH}=4,57-$ 4,78 , що пояснюють початком фази ацетогенезису. Оптимальним для анаеробного розкладу $є \mathrm{pH}$ в межах 77,5 , тому рН в реакторах коригували до 7,5 шляхом добавляння невеликої кількості розчину $\mathrm{NaOH}$. Реактори закривали герметичними корками із газовідвідними трубками 2. Утворений біогаз збирався через систему газовідвідних трубок 2 у градуйовані колби 3 , які були занурені у наповнені водою ванни 6. pН води підтримувався нижче 5. Оскільки за низьких $\mathrm{pH}$ неорганічний вуглець перебуває у формі $\mathrm{CO}_{2}$, це давало змогу уникнути розчинення вуглекислого газу, присутнього у біогазі, у воді. Реактори обмотували чорним поліетиленом для недопущення потрапляння світла та поміщали у водяну баню 5, в якій підтримувалась температура 34 ${ }^{\circ} \mathrm{C}$ (мезофільні умови) за допомогою терморегулятора 4. Вміст реакторів перемішували впродовж 1 хв кожних 2 дні. Загальна тривалість досліджень становила 35 діб. Для оперативного контролю динаміки накопичення біогазу у градуювальник колбах 3 використовувалась система відеоконтролю, яка складалась із веб-камери 7, зображення із якої подавалось на монітор 8 (див. рис. 2). Система давала змогу досягти безперервності контролю за кількістю утвореного біогазу. Загальний вигляд зображення, що передавалось на монітор, показано на рис. 3.

Результати досліджень динаміки синтезу біогазу із біомаси ціанобактерій, подано на рис. 4. Як видно із цих даних, у разі біорозкладу активного мулу без добавок ціанобактерій, із великою часткою ймовірності можна прийняти, що процес виділення біогазу відбу- 
вається із постійною швидкістю. У разі ж виділення біогазу в процесі біорозкладу біомаси ціанобактерій (після оброблення в віброкавітаційному полі) криві динаміки виділення біогазу мають S-подібну форму.

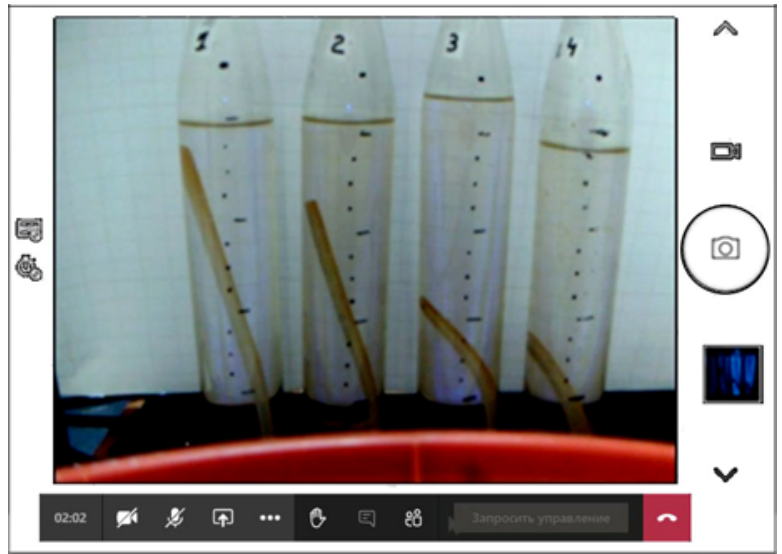

Рис. 3. Зображення градуювальник колб у режимі реального чаcy $(16.12 .2020 \mathrm{p}$.)

Це підтверджує, що процес має автокаталітичний характер і може бути описаний рівнянням Міхаеліса Ментена. Метою подальших досліджень буде більш докладніше дослідження процесу за різних умов його реалізації, щоб встановити кінетичні константи, які можуть бути використані для розрахунку реальних процесів.

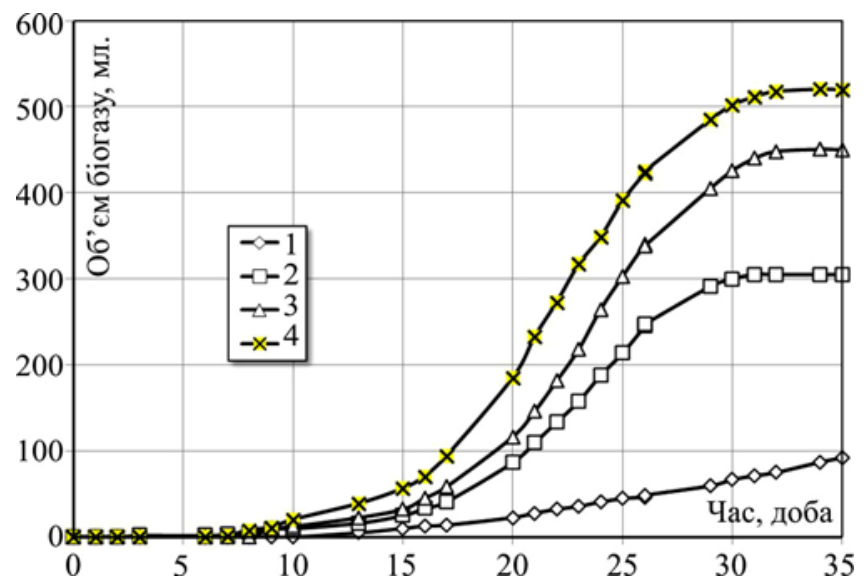

Рис. 4. Динаміка біорозкладу біомаси ціанобактерій та активного мулу в мезофільних умовах залежно від тривалості попереднього віброкавітаційного оброблення (1 - активний мул; 2, 34 - суспензія ціанобактерій, тривалість віброкавітаційного оброблення якої становить відповідно 5, 10 та 15 хв).

Результати, наведені на рис. 4, свідчать про те, що віброкавітаційне оброблення дає змогу значно збільшити інтенсивність синтезу біогазу, а також збільшити об'єм його утворення. Так, із збільшенням часу віброкавітаційного оброблення відповідно від 5 до 10, а потім до 15 хв, кількість синтезованого біогазу відповідно збільшилась в 1,5 і 1,7 раза.

Проводили також дослідження щодо перспектив використання залишку біомаси після закінчення процесу метаногенезу (дигестату). Встановлено, що дигестат $є$ біодобривом, яке містить біологічно активні речовини та мікроелементи. Основною перевагою біодобрив перед традиційними добривами $є$ форма, доступність та збалансованість всіх елементів живлення, високий рівень гуміфікації органічної речовини. Органічна речовина слугує потужним енергетичним матеріалом для грунтових мікроорганізмів, тому після внесення в грун- ті відбувається активізація азотофіксуючих та інших мікробіологічних процесів. Це створює позитивний вплив на грунтову родючість та поліпшення фізико-механічних властивостей грунту. Використання біодобрив для вирощування сільськогосподарських культур дасть змогу знизити використання хімічних добрив, які чинять негативний вплив на якість та родючість грунтів. А в разі створення композиції дигестат - природні дисперсні сорбенти вдасться отримати ефективне органомінеральне добриво.

\section{Висновки}

Аналіз отриманих результатів дає підстави стверджувати про ефективність попереднього оброблення біомаси ціанобактерій перед реалізацією процесу метаногенезу. Доведена перспективність застосування віброкавітаційного оброблення. Наведено опис віброкавітатора, який дає змогу обробляти біомасу ціанобактерій у безперервному режимі. Показано, що найбільша інтенсивність процесу метаногенезу та максимальна кількість синтезованого біогазу була у разі попереднього віброкавітаційного оброблення біомаси ціанобактерій упродовж 15 хв. Встановлено, що криві динаміки синтезу біогазу мають s-подібну форму і можуть бути описані рівнянням Міхаеліса - Ментена. Запропоновано використовувати дигестат як ефективне органічне добриво, а в разі створення композиції їх природними дисперсними сорбентами - як органо-мінеральне добриво.

\section{References}

1. Chisti, Yu. (2007). Biodiesel from microalgae. Biotechnology Advances, 25(3), 294-306.

2. Choi, S. P., Nguyen, M. T., \& Sim, S. J. (2010). Enzymatic pretreatment of Chlamydomonas reinhardtii biomass for ethanol production. Bioresour Technol, 101, 5330-5336. https://doi.org/10.1016/j.biortech.2010.02.026

3. Dogaris Ioannis, Ammar Ehab, \& Philippidis George, P. (2020). Prospects of integrating algae technologies into landfill leachate treatment. World Journal of Microbiology and Biotechnology, 36(39), 25-34. https://doi.org/10.1007/s11274-020-2810-y

4. Malovanyi, M. S., Nykyforov, V. V., Kharlamova, O. V., \& Synelnikov, O. D. (2015). Otsiniuvannia ekolohichnoi nebezpeky v akvatoriiakh Dniprovskykh vodoskhovyshch vnaslidok nekontrolovanoho rozvytku tsianobakterii. Scientific Bulletin of UN$F U, 25(6), 159-164$. Retrieved from: https://nv.nltu.edu.ua/Archive/2015/25_6/28.pdf. [In Ukrainian].

5. Malovanyi, M. S., Synelnikov, O. D., Kharlamova, O. V., \& Malovanyi, A. M. (2014). Optymalni umovy otrymannia enerhii iz tsianobakterii. Khimichna promyslovist Ukrainy, 5, 39-43. [In Ukrainian].

6. Malovanyy, M., Nikiforov, V., Kharlamova, O., \& Synelnikov, O. (2016). Production of renewable energy resources via complex treatment of cyanobacteria biomass. Chemistry \& Chemical Technology, $\quad 10(2)$, https://doi.org/10.23939/chcht10.02.251

7. Malovanyy, M., Nykyforov, V., Kharlamova, O., Synelnikov, O., \& Dereyko, Kh. (2016). Reduction of the environmental threat from uncontrolled development of cyanobacteria in waters of Dnipro reservoirs. Environmental Problems, 1, 61-64.

8. Nikiforov, V. V. (2010). O prirodoohrannyih i energosberegayuschih perspektivah ispolzovaniya sinezelenyih vodorostey. Promyishlennaya botanika, 10, 193-196. [In Russian].

9. Nykyforov, V. V., Malovanyy, M. S., Aftanaziv, I. S., Shevchuk, L. I., \& Strutynska, L. R. (2019). Developing a technology for treating blue-green algae biomass using vibro-resonance cavitators. Naukovyi Visnyk Natsionalnoho Hirnychoho Universytetu, 6, 181-188. https://doi.org/10.29202/nvngu/2019-6/27 
10. Rodolfi, L., Zittelli, G. C., Bassi, N., Padovani, G., Biondi, N., \& Bonini, G. (2009). Microalgae for oil: strain selection, induction of lipid synthesis and outdoor mass cultivation in a low-cost photobioreactor. Biotechnology and Bioengineering, 102(1), 100-112.
11. Shevchuk, L. I., Aftanaziv, I. S., Strohan, O. I., \& Starchevskyi, V. L. (2013). Nyzkochastotni vibrorezonansni kavitatory. Lviv: Vydavnytstvo Lvivskoi politekhniky, 260 p. [In Ukrainian].

\section{S. Aftanaziv', Yu. A. Balandiuk', M. S. Mallovanyy', I. S. Tymchuk', V. M. Zhuk', M. L. Kopiy}

${ }^{1}$ Lviv Polytechnic National University, Lviv, Ukraine ${ }^{2}$ Ukrainian National Forestry University, Lviv, Ukraine

\section{INFLUENCE OF CYANOBACTERIA SUSPENSION VIBROCAVITATION TREATMENT ON THE BIOGAS SYNTHESIS INTENSITY}

The influence of cyanobacterial suspension vibrocavitation treatment on the intensity of biogas synthesis from their biomass and the completeness of biomass decomposition has been studied. The problem importance of cyanobacterial biomass utilization by using it as a raw material for biogas production has been shown. Possible ways of cyanobacteria pre-treatment with the aim of cell membranes destruction and increase of mass transfer surface for the cyanobacteria biomass methanogenesis process have been studied. It is shown that a promising method of cyanobacteria biomass pre-treatment is vibrocavitation treatment. As a result of this treatment it is possible to increase the biodegradation degree several times and the intensity of methanogenesis from the cyanobacteria biomass. The advantage of vibrocavitation processing is also the possibility of its implementation in a continuous mode. The design of a vibrating electromagnetic cavitator for homogenization of cyanobacterial biomass and increase of biomass availability for biodegradation due to destruction of cyanobacterial cell walls is proposed. Studies have been conducted to establish the effectiveness of previbrocavitation treatment of cyanobacterial suspension on the intensity of biogas synthesis from processed biomass. A laboratory model of a periodic action vibrocavitator was used for the research. To study the dynamics of methanogenesis from the cyanobacteria suspension, a unit was designed that allows controlling the intensity and completeness of the isolated biogas using video surveillance. Studies have shown that kinetic curves have an S - like shape and can be described by the Michaelis - Menten equation. It is established that vibrocavitation treatment can significantly intensify the methanogenesis process and increase the completeness of biomass biodegradation. With increasing processing time from 5 to 15 minutes, the amount of biogas obtained increases 1.7 times. Excess biomass after biodegradation (digestate) is proposed to be used as an effective organic (and in the case of a composition with natural sorbents - as an organo - mineral) fertilizer.

Keywords: eutrophication; biomass; biodegradation; biological treatment; intensity; methanogens; digestate. 